Reprod. Nutr. Dévelop., 1981, 21 (6 A), 1009-1014.

\title{
Effects of changes of photoperiod on gametogenesis in the rainbow trout (Salmo gairdneri)
}

par R. BILLARD, Pierrette REINAUD, P. LE BRENN.

Laboratoire de Physiologie des Poissons, I.N.R.A. 78350 jouy en Josas, France.

Summary. After their first reproductive period, adult male and female rainbow trout were put under three different photoperiodic regimes between January and June : (1) short daylength (6 h of light/day), (2) decreasing daylength (16L : 8D $\rightarrow 10 \mathrm{~L}: 14 \mathrm{D})$, (3) skeleton photoperiod consisting of short day-length $(6 \mathrm{~L}: 18 \mathrm{D})$ with a one-hour flash at various times during the dark cycle in a decreasing daylength fashion (between $16 \mathrm{~L}$ and 10L), i.e. at the end of the daylight period of the preceding group. The rearing temperature was $15^{\circ} \mathrm{C}$. After the fish were killed in June, it was found that decreasing daylength (group 2) had stimulated vitellogenesis. In that group, spermatogenesis was also highly stimulated in all the males, and some were in spermiation. No significant stimulation of vitellogenesis was observed in any of the groups of females which showed a follicular diameter of less than $1 \mathrm{~mm}$. Spermatogenesis had not begun in any males of group 1 and 3 but the testicular cycle was slightly advanced in group 3 in which residual spermatozoa had disappeared from the lobules, while they still subsisted in group 2.

The hypothesis proposing the present pattern of photosensitive phase, shifting between $16 \mathrm{~L}$ and $10 \mathrm{~L}$ (group 3 ) during the gametogenetic cycle, cannot explain the stimulatory effect of the decreasing photoperiod (group 1 ).

\section{Introduction.}

Salmonid gametogenesis occurs naturally in mid or late summer under conditions of decreasing photoperiod and temperature. When the annual photoperiod is condensed experimentally into 9 to 6-month periods, gametogenesis is speeded-up and the normal spawning period occurs earlier (Hoover and Hubbard, 1937 ; Hazard and Eddy, 1951 ; Nomura, 1962 ; Henderson, 1963 ; Whitehead et al., 1978). A decreasing photoperiod, beginning just at the end of the reproductive cycle and diminishing from $16 \mathrm{~L}$ to $10 \mathrm{~L}$ in the 6 months between January and June, induces complete gametogenesis at a wide range of temperatures. If, during the same period, an $8 \mathrm{~L}$ photoperiod is reduced in the same way, but from $8 \mathrm{~L}$ to $0 \mathrm{~L}$, the gonads are not stimulated (Breton ef al., unpublished data). Moreover, in our laboratory a constant long (16L : 8D) or short (8L : 16D) photoperiodic regime, given between January and June, is never stimulatory (Breton and Billard, 1977). It thus appears that when the photoperiod is decreased from $16 \mathrm{~L}$ to $8 \mathrm{~L}$, just after the cycle is over, the effect is more stimulatory than with constant photoperiods. A photosensitive phase, shifting gradually between 16 and $8 \mathrm{~L}$ during this 6-month period, might explain the stimulatory effect of the decreasing photoperiod. 
This hypothesis was tested during the present study in which male and female rainbow trout were given a decreasing photoperiod (16L : 8D $\rightarrow 10 \mathrm{~L}: 14 \mathrm{D})$ in 6 months or a short photoperiod (6L : 18D) with or without one extra hour of light at a time which shifted from $16 \mathrm{~h}$ after lights-on to $10 \mathrm{~h}$ after during a 6-month experimental period. The latter light regime is often referred to as a skeleton photoperiod.

\section{Material and methods.}

Fish from a « Lubin » population, reared in the fishfarm laboratory of Gournaysur-Aronde, were used in this sutdy. They were brought to the laboratory on December 17,1979 and stocked in recycled, filtered water (Petit, 1974) at 8 to $10^{\circ} \mathrm{C}$ under natural photoperiod. The fish were adults, having already completed the first reproductive cycle. At the beginning of the experiment, the males, in which spermiation had started at the end of November, emitted large amounts of sperm $(\geqslant 1 \mathrm{ml})$ when the abdomen was squeezed. The sperm was collected in tubes and the total volume measured to the nearest $0.1 \mathrm{ml}$. The females, which had ovulated between December 20 and January 5 , were emptied of ova before being put into the experimental tanks on January 5, 1980.

The experimental arrangement, described previouly (Fayard, 1975 ; Breton and Billard, 1977), consisted of 3 rooms each containing two $0.5 \mathrm{~m}^{3}$-tanks $(2.08 \times 0.8 \times 0.35)$ supplied with recycled water regulated to $15{ }^{\circ} \mathrm{C}$. The flow to the tanks was $3 \mathrm{~m}^{3} / \mathrm{h}$; each tank contained 12 male or female fish, or about $8 \mathrm{~kg}$ tolal weight. Before the experiment began, the recycling system had been loaded gradually with other fish to activate bacterial filtration (Marie, 1979).

Except on Sunday, the fish were fed twice daily at a ration of one percent of their

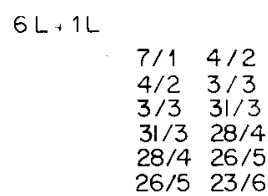

$6 \mathrm{~L}$

$1 /$

$16 \mathrm{~L} \rightarrow \mathrm{OOL}$
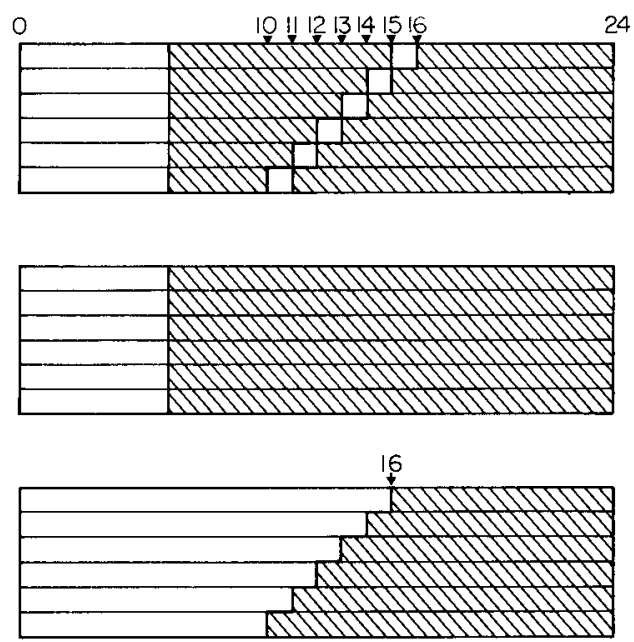

FIG. 1. - Photoperiod regime in the 3 experimental groups. Top : skeleton photoperiod group L6 $+1 \mathrm{~L}$ shifting from 16 to $10 \mathrm{~h}$ after lights-on ; middle : constant $6 \mathrm{~L}$ of light per day ; botton : light phase of the nycthemere shifting from $16 \mathrm{~h}$ to $10 \mathrm{~h}$. 
body weight per day in trout pellets. This amount was adjusted weekly to take account of growth and mortality. Routine care consisted of a weekly, 15-min treatment with malachite green (5 mg/l) up to April 13, then with Agroseptyl (4 mg/l) until the experiment ended; the filter was washed and back-flushed 3 times a week with compressed air. The nitrite, nitrate and ammonia levels were assayed twice a week using an $\mathrm{HACH}$ kit. If these compounds exceeded tolerable limits, the water was changed.

Between January 4 and 7 , all the fish were given a photoperiod computed on the natural photoperiod; from January 7 , the experimental design (fig. 1) was used. Lights-on and lights-off were controlled by a time clock without any transition. The lights were turned on at 7 a.m. GMT, or 8 a.m. local winter time (before March 30, 1979) and 9 a.m. local summer time.

The fish were examined weekly under phenoxyethanol anesthesia $(0.3 \mathrm{ml} / \mathrm{l})$ to check their health and the development of spermiation in the males.

At the end of the experiment, all the fish were fasted for 3 days and then killed. Their gonadal, visceral and liver weights were noted as well as the diameter $(>1 \mathrm{~mm})$ of the follicles in exogenous vitellogenesis which were measured with a binocular graticule. The stage of testicular development was evaluated by gross examination according to Billard and Escaffre (1975).

The results in the tables are the means $\pm S D$; the t-test was used for statistical comparison.

\section{Results.}

At the end of the experimental period, ovarian growth and follicular size in the female fish were only stimulated under the decreasing photoperiod $(P<0.01$ as compared to the other two groups) (table 1), although no ovulation was detected. The other parameters studied did not differ significantly in the three groups, except for a slightly higher mortality and a lower HSI in the group given the skeleton photoperiod.

In males, the situation was analogous (table 2); gonadal weight was strongly stimulated in the group under the decreasing photoperiod $(P<0.01$ as compared to

TABLE 1

Effects of various photoperiods applied between January and June on reproduction in rainbow trout females GSI and HSI are given in p. 100 of total body weight *

\begin{tabular}{|c|c|c|c|c|c|}
\hline \multirow[b]{2}{*}{$\mathrm{n} \ldots \ldots \ldots \ldots \ldots \ldots$} & Constant 6L & \multicolumn{2}{|c|}{$6 L+1 L$} & \multicolumn{2}{|c|}{$16 \mathrm{~L} \rightarrow 10 \mathrm{~L}$} \\
\hline & 10 & & 7 & & 9 \\
\hline $\begin{array}{l}\text { Body weight }(g) \ldots \ldots \ldots \\
\text { Visceral weight } \ldots(g) \ldots \ldots \\
\text { HSI (p. 100) }{ }^{*} \ldots \ldots \ldots \ldots \\
\text { GSI (p. 100) }{ }^{*} \ldots \ldots \ldots \ldots \\
\text { Follicular diameter (mm) }\end{array}$ & \begin{tabular}{ccc}
632 & \pm 184 \\
$56.9 \pm$ & \pm 26.3 \\
$2.06 \pm$ & 0.56 \\
$1.04 \pm$ & 0.21 \\
\multicolumn{2}{c}{ \pm} &
\end{tabular} & $\begin{array}{l}811 \\
70.9 \\
1.78 \\
1.28\end{array}$ & $\begin{array}{lc} \pm & 171 \\
\pm & 24.3 \\
\pm & 0.36 \\
\pm & 0.53 \\
<1 & \end{array}$ & $\begin{array}{l}810 \pm \\
61.3 \pm \\
2.48 \pm \\
7.61 \pm \\
2.94 \pm\end{array}$ & $\begin{array}{ll} \pm & 164 \\
\pm & 15.2 \\
\pm & 0.42 \\
\pm & 2.91 \\
\pm & 1.05\end{array}$ \\
\hline
\end{tabular}

* HSI : hepatosomatic index; GSI : gonadosomatic index.

** $P<0.01$ as compared to the other groups. 
the other groups) : 7 out of 10 males were actively spermiating (sperm production $\geqslant 1 \mathrm{ml}$ ), and when autopsied, all showed a white, milky substance in the testis, indicating that gametogenesis had been achieved. In the group submitted to the skeleton photoperiod, we found no sign of spermatogenesis at the end of the experiment. The

TABLE 2

Effect of various photoperiodic regimes given between January and June on spermatogenesis in rainbow trout males

\begin{tabular}{|c|c|c|c|c|}
\hline Light regime/24 h & Constant 6L & $6 L+1 L$ & \multicolumn{2}{|c|}{$16 \mathrm{~L} \rightarrow 10 \mathrm{~L}$} \\
\hline$\ldots$ & 11 & 11 & & 10 \\
\hline $\begin{array}{l}\text { Body weight }(g) \ldots \ldots \ldots \ldots \\
\text { Visceral weight }(g) \ldots \ldots \ldots \ldots \\
\text { HSI }(p .100) \ldots \ldots \ldots \ldots \ldots \ldots \\
\text { GSI }{ }^{*}(\text { p. } 100) \ldots \ldots \ldots \ldots \ldots \\
\text { No. of males in spermiation.. }\end{array}$ & $\begin{array}{ll}817 & \pm 130 \\
68.4 \pm & \pm 19.3 \\
1.67 \pm & 0.36 \\
1.99 \pm & 0.53 \\
& 0\end{array}$ & $\begin{array}{ll}771 & \pm 81 \\
65.2 & \pm 11.2 \\
1.87 & \pm 0.31 \\
0.53 & \pm \\
& 0.28\end{array}$ & $\begin{array}{c}810 \\
51.2 \\
1.71 \\
4.81\end{array}$ & $\begin{array}{l} \pm 69 \\
\pm 15.3 \\
\pm \quad 0.26 \\
\pm \\
7\end{array}$ \\
\hline
\end{tabular}

" At the beginning of the experiment, the GSI mean was $3.01 \pm 0.75 ; n=7$ (extreme : $1.75 \pm 3.84$ ). * $P<0.01$ as compared to the group receiving $6 L+1 L$.

testes were filiform, with residues of the previous sperm cycle in the form of grayish nodules in the testes and whitish fluid in the vas deferens. The sifuation was slightly different in the group given 6L : 18D. Four of the 11 animals had rosy-colored testes which is an indication of the onset of spermatogetic activity. During the experiment, spermiation stopped more abruptly under decreasing photoperiod than in the other two groups. Gross histological examination of the testes showed that spermatogenesis was active in the group on the schedule of $16 \mathrm{~L}: 8 \mathrm{D} \rightarrow 10 \mathrm{~L}: 14 \mathrm{D}$. In the group under constant photoperiod (6L : 18D), spermatogenesis was not stimulated, and the remnants of spermatozoa from the previous spermatogenetic cycle were still present in the testes, as shown by the presence of whitish nodules. Spermatogenesis was not stimulated in the skeleton photoperiod group either but the testes were free of spermatozoa. Visceral weight, including visceral fat, was slightly lower in the decreasing photoperiod group, but the differences were not significant. There was no difference in the liver weight between the 3 groups.

\section{Discussion.}

After 6 months of exposure to the experimental photoperiods, only the decreasing one $(16 \mathrm{~L}: 8 \mathrm{D} \rightarrow 10 \mathrm{~L}: 14 \mathrm{D})$ stimulated gametogenesis. In the females, gonadal size increased markedly and was 6 to 7 times greater than in the other groups; follicular size reached $3 \mathrm{~mm}$ and the oocytes were undergoing vitellogenesis. No such change was seen in the fish under the skeleton photoperiod or in those under constant short days. Similarly, male spermatogenesis was stimulated only under the decreasing photoperiodic regime. Although there was no spermatogenetic activity in the skeleton photoperiod group, the testicular cycle was more advanced than in the group under constant 
photoperiod (6L : 18D) since the spermatozoa had been eliminated from the testis, as shown by the low GSI in table 2. Billard (unpublished) has shown in rainbow trout that a new spermatogenetic cycle starts only after the spermatozoa of the previous cycle have been eliminated.

It therefore appears that the cycle is slightly more advanced in the skeleton photoperiod group ; this might be due to the extra hour of light they received rather than to the position of that hour in the nycthemeron.

The stimulatory effect of the decreasing photoperiod regime, given between January and June, has been previously observed in the same species (Breton and Billard, 1977 ; Billard and Breton, 1977). However, the GSI was slightly higher than in the present experiment, resulting possibly from a more extensively decreased photoperiod $(16 \mathrm{~L}: 8 \mathrm{D} \rightarrow 8 \mathrm{~L}: 16 \mathrm{D})$.

It should be noted that only a decreasing photoperiod is stimulatory between January and June. If the trout are put under short (8L) or long (16L) daylength or increasing daylength (16L $\rightarrow 24 \mathrm{~L}$ in 6 months) during these months of the year, gametogenesis and gamete release are sometimes delayed by several months (Bourlier, 1979).

The present experiment shows that there is no photosensitive phase in the rainbow trout at the end of the light period given in natural conditions. Such a phase at the end of the light period has been demonstrated in several species, such as the stickleback (Baggerman, 1957), in which gametogenesis occurs during increasing daylength, the Indian catfish, Heferopneustes fossilis (Sundararaj and Vasal, 1976) and Oryzias latipes (Chan, 1976). The pattern must be different in such species as salmonids in which gametogenesis occurs in the decreasing light period. However, the possibility of a photosensitive phase in salmonids remains; it may be stable (and not shift as hypothesized in the present work) during the last part of the cycle, and would be located in the range of 10 to $16 \mathrm{~L}$. This photosensitive phase might affect fish in the wild either when the natural daylength of the photoperiod is rising (leading to summer reproduction) or decreasing (leading to winter-autumn reproduction). Experiments to test this hypothesis are now in progress in our laboratory.

Reçu en février 1981.

Accepté en juin 1981.

Acknowledgements. - This work was supported by the I.N.R.A. Thanks are due to Dr. N. Bromage who criticized this paper and to Ms. Alice Daifuku who helped in editing the English manuscript.

Résumé. Des truites arc-en-ciel mâles et femelles adultes ayant achevé leur 1er cycle reproducteur sont sou mises a trois régimes photopériodiques entre janvier et juin; Groupe 1 : jours courts $(6 \mathrm{~h}$ de lumière par jour $6 \mathrm{~L}-18 \mathrm{D})$; Groupe 2 : photopériode décroissante passant de 16L-8D à 10L-14D en 6 mois; Groupe 3 : jours courts de 6 h de lumière + un flash de $1 \mathrm{~h}$ qui vient se placer à la fin de la période claire du groupe 2 . La température d'élevage est de $15^{\circ} \mathrm{C}$ à la fin de l'expérience en juin. La vitellogenèse et la spermatogenèse sont stimulées dans le groupe 2 et quelques mâles sont en spermiation. Dans les groupes 1 et 2 , il n'y a pas de stimulation notable de la vitellogenèse et le diamètre des follicules reste inférieur à $1 \mathrm{~mm}$; la spermatogenèse n'a pas commencé chez aucun des mâles mais le cycle testiculaire 
est légèrement plus avancé dans le groupe 3 où les spermatozoïdes ont été entièrement éliminés alors que des spermatozoïdes résiduels subsistent dans le groupe 2 .

La présente hypothèse proposant le déplacement d'une phase photosensible de 16L à $10 \mathrm{~L}$ pendant le cycle gamétogénétique n'explique pas les effets stimulants de la photopériode décroissante observés dans le groupe 1.

\section{References}

BAGGERMAN B., 1957. An experimental study on the timing of breeding and migration in the threespined stickleback (Gasterosfeus aculeafus L.). Arch. neerl. Zool., 12, 105-317.

BILLARD R., ESCAFFRE A. M., 1975. Identification des stades de la spermatogenèse de la truite fario d'après la morphologie des gonades et la spermiation. Bull. fr. Pisc., 256, 111-113.

BILLARD R., BRETON B., 1977. Sensibilité à la température des différentes étapes de la reproduction chez la truite Arc-en-ciel. Cah. Lab. Moniereau, 5, 5-24.

BOURLIER A., 1979. Contribution au contrôle de la reproduction chez les salmonidés : influence des longues photopériodes au cours de deux cycles de maturation chez la truite Arc-en-ciel (Salmo gairdneri). D.E.A. Univ. Paris VI. 120, pp.

BRETON B., BILLARD R., 1977. Effects of photoperiod and temperature on plasma gonadotropin and spermatogenesis in the rainbow trout (Salmo gairdneri Richardson). Ann. Biol. anim. Bioch. Biophys., 17, 331-340.

CHAN K. K. S., 1976. A photosensitive daily rhythm in the female medaka, Oryzias latipes. Can. J. Zool., 54, 852-856.

FAYARD G., 1975. Efude d'un système de contrôle et de régulation hydraulique et thermique applicable à la recherche hydrobiologique. Notice techn. CEA-NT-50.

HAZARD T. P., EDDY R. E., 1951. Modification of the sexual cycle in brook trout (Salvelinus fontinalis) by control light. Trans. am. Fish Soc., 80, 158-162.

HENDERSON N. E., 1963. Influence of light and temperature on the reproductive cycle of the eastern brook trout, Salvelinus fontinalis (Mitchell). J. Fish Res. Bd. Can., 20, 859-897.

HOOVER E. E., HUBBARD H. G., 1937. Experimental modification of the sexual cycle in trout by control of light. Science, N. Y., 86, 425-426.

MARIE D., 1979. Conception, réalisotion et gestion d'un recyclage d'eau en pisciculfure. D. E. S., Univ. Paris VI, 28 pp.

NOMURA M., 1962. Studies on reproduction of rainbow trout, Salmo gairdneri, with special reference to egg taking. III. - Acceleration of spawning by control of light. Bull. Jap. Soc. sci. Fish, 28, 1070-1076.

PETIT J., 1974. Recyclage ef épuration en pisciculture : étude théorique ef bibliographique. Coll. Aquacult. CNEXO, Brest, oct. 1973, 445-470.

SUNDARARAJ B. I., VASAL S., 1976. Photoperiod and temperature control in the regulation of reproduction in the female catfish Heteropneusies fossilis. J. Fish Res. Bd Can., 33, 959-973.

WHITEHEAD C., BROMAGE N. R., FORSTER J. R. M., MATTY A. J., 1978. The effects of alterations in photoperiod on ovarian development and spawning time in the rainbow trout (Salmo gairdneri). Ann. Biol. anim. Bioch. Biophys., 18, 1035-1043. 